\title{
A diachronic analysis of the Crasna hydronim field ${ }^{\dagger}$
}

\author{
Daniela Butnaru* \\ "A. Philippide" Institute of Romanian Philology, Str. Th. Codrescu 2, 700481 Iași, Romania
}

\author{
Article info \\ History: \\ Key words: \\ toponymic field \\ polarization \\ differentiation \\ diachrony \\ Crasna
}

Received July 23, 2018

Accepted August 21, 2018

Published October 7, 2018

\begin{abstract}
This study aims at analyzing the formation (through differentiation and polarization processes as described by Dragoș Moldovanu) as well as the evolution of the toponymic field developed from the hydronym Crasna, the name of a tributary of the Bîrlad River. The organization of such a toponymic ensemble around a main toponym which denominates a (socio)geographical object regarded by denominators as being of major importance when compared to other toponyms in the area represents a natural process that mirrors the reality in the field. Our approach is based on information extracted from document collections, dictionaries, maps and monographs. The synchronic and diachronic study of Crasna toponym field revealed the relationships between toponyms, the denominative concurrence, the existence of certain homonyms, as well as the evolution of the toponymic structure.
\end{abstract}

\section{Introducere}

The aim of this study is to trace the formation of a rich toponymic field developed around the name of the Crasna Stream through various structural processes of polarization and differentiation. Crasna is a 63.8 $\mathrm{km}$ long tributary of the Bîrlad River with a drainage basin of $564 \mathrm{de} \mathrm{km}^{2}$ in the counties of Iași and Vaslui (Ujvári, 1972, p. 504). Moreover, we aim at pointing out to the evolution of topical names, both from the perspective of the designated objects and the expression viewpoint. The toponyms analyzed in this study were extracted from document collections, dictionaries, maps and monographs.

\section{Toponymic field, polarization and differentiation}

Toponymic fields are aggregates of place names formed by denominators starting from certain nucleustoponyms meant to designate important (socio)geographical objects in a given area. "The common element of the polarized group is the name of this central element; the distinctions are made by means of entopic terms with a toponymic function" (Moldovanu, 1972, p. 81). Polarization is the process of creation of toponymic derivates that designate neighboring objects belonging to different geographical categories, while the process of differentiation involves the designation of parts of the same geographical object (Moldovanu, 2010, p. 18-19) ${ }^{1}$. The observation of place names within toponymic fields may provide information related to the relationship between the name and the designated object, the connection between certain toponyms, as well as data about certain toponyms that are no longer used. The creation of place names starting from other toponyms was also mentioned by Bolocan (1977), who spoke of toponymic transfer, or by Rezeanu (2014, p. 19), who coined the notion of derivational toponymic extension.

\footnotetext{
†This paper was presented at the symposium “Toponymy between history, geography and linguistics”, Iași, May $10^{\text {th }}, 2018$. *Email address:d_butnaru@yahoo.com.

${ }^{1}$ Details related to the toponymic fields theory, accompanied by numerous examples, can be found in the introduction of MDTM.
} 


\section{The primary toponym}

There is a primary toponym (nucleus) in the centre of the field; derivate/secondary toponyms are formed from this nucleus, including it in their structure. A most important stage in establishing the polarizing nucleus is the identification of the toponymic etymology. As far as the Crasna toponyms identified frequently on the Romanian territory are concerned, two main directions can be distinguished.

According to certain historians and linguists the meaning of this name is 'red'. This viewpoint is shared, for instance, by Gh. Ghibănescu in Schiță istorică despre Vaslui, cu care începe volumul al XV-lea al colecției Surete şi izvoade: „Crasna (Sl. красенъ, красніи) red. The resulting meaning is Roşia Water [The Red Water]” (Ghibănescu, 1926, p. III). Moreover, Emil Petrovici, an expert on Slavonic languages, states that the Romanian equivalent of Crasna is Roşia [The Read Stream] (1970, p. 248).

Other linguists proposed the meaning 'beautiful' for the adjective this toponym is based on. Iorgu Iordan (1963, p. 113) sends to OSl. krasinü 'beatiful', Bulg. krasen 'beautiful, pretty' and Sl. krasa 'beauty'. Nicolae Drăganu (1933, p. 476) indicates the origin from Sl. krassnz 'speciosus', 'amœnus'. In an article about the tendency of the Romanian chancelleries to slavicize names of places, Alexandru I. Gonța goes even further and asserts that in fact the toponym Crasna could actually represent the translation of the Romanian toponym by the Moldavian clerks and it consequently should be read in Mediaeval documents as Pîrîl Frumos (Gonța, 1977, p. 264). However, Mircea Ciubotaru points to the fact that using this toponym in order to illustrate the official Medieval slavicizing phenomenon is wrong, since this hydronym is of "old Slavonic origin" (1992, p. 459), its "older meaning" being 'beautiful' (Ciubotaru, 2001, p. 60) 2.

Both meanings of the etymon seem verisimilar as far as their geographical motivation is concerned. The studies regarding the composition of the soil in the area crossed by this stream indicate clay soil as the main characteristic of the area (Gugiuman et al., 1988, p. 61). This type of soil could make the water appear red when it is clear. On the other hand, old documents reveal that in the lower and middle basin of the River Crasna there were many villages where one could find lakes, mills, apiaries, orchards, vineyards and gardens (DRH, A, III, p. 254; VIII, p. 104-105; IX, p. 178, 314-315; XIX, p. 561-562; CDM, IV, p. 301 and others), which indicate that the area was favorable for human settlements and agriculture. A "beautiful stream" is a stream of water "surrounded by slow slopes, where people could live and work in good conditions" (Moldovanu, 2010, p. 145).

According to local legends, the name of the Crasna estate could originate from the name of one of the soldiers of Stephen the Great, Crasnaș, whose descendants divided the property into three parts: Crăsnița, Brădicești and Dolheșt (MDG, III, p. 169) ${ }^{3}$.

\section{Toponymic derivates}

Documented for the first time in a copy of a document possibly written on May $1^{\text {st }}, 1406$ (DRH, A, I, p. 28), this hydronym has become the nucleus of a toponymic field made of several secondary/derivate toponyms that designate (socio)geographical objects situated in the drainage basin of Crasna. First degree derivates, second degree derivates and so forth are formed from the main toponym. While presenting the elements that compose this toponymic ensemble, which is also exemplified in the Annex, we shall reveal some of the issues that challenged us in our attempt to rebuild the field and establish the relationships between the names of places that form this field.

The Crasna River analyzed in this study flows into the Bîrlad River in an area whose name resulted through toponymic differentiation, Gura Crasnei [The Mouth of Crasna], a name attested in 1586 (DRH,

\footnotetext{
${ }^{2}$ See also Vasmer (1967, p. 368; from OSl. krassns 'speciosus, perpulcher, iucundus, amœnus'), Grinčenko (1925, p. 836; Красинй 'wonderful, beautiful, good'). Cf. noun kpaca 'venustas, pulchritudo' (Miklosich, 1927, p. 269; 1862, p. 309; Šmilauer, 1970, p. 100).

${ }^{3}$ The anthroponym Crasnăș, attested in documents from the $15^{\text {th }}$ to the $17^{\text {th }}$ centuries (Gonța, 1995, p. 136-137), gave the name of Crăsnășenii village, also situated on the Crasna Stream.
} 
A, VIII, p. 104). In the very same place there existed, in the first half of the $19^{\text {th }}$ century, a post office named Gura Crasnei near which a village bearing the same name, first attested in 1871 (TTRM, $\mathrm{I}_{1}$, p. 308) was founded. By the end of the $19^{\text {th }}$ century, a railway station was built here, belonging to the CrasnaHuși railway built in 1888 (Lupu \& Kalinca, 1990, p. 1). Thus, in some documents of the time the place was mentioned as Gara Crasnei [The Railway Station of Crasna] (ibidem) or, with the determinant in nominative, Gara Crasna [Crasna Railway Station] (Chiriță, 1893, p. 83). The two collocations occur alternatively in official documents until 1924, when the village is called Crasna and the name it still holds today (TTRM, $\mathrm{I}_{1}$, p. 308).

The area from the springs of this valley is mentioned in old documents under the name of Obîrsia Crasnei [The Headwaters of Crasna] (DIR, A, XVI-I, p. 221, in the year 1523) or, using other entopic terms, Fundul Crasnei [Crasna Bottom] (Ghibănescu, 1913, p. 321, in the year 1668) and Fundătura Crasnei (CDM, III, p. 284, in the year 1666). There was also an estate in the area called Fundul Crasnei, where a village with the same name was subsequently settled (today it is called Rotăria, see infra).

The process of toponymic differentiation led to the formation of the hydronym Crăsniţa by derivation with the diminutive suffix -ița. Also present in the name Valea Crăsnița [Crăsnița Valley], it names one of the first right-side tributaries of the Crasna stream, upstream the village of Dolhești in the county of Iași (CDM, V, p. 202, year 1708). The name of the area situated in the vicinity of the stream sources was formed through toponymic differentiation, Obîrșia Crăsniței [The Headwaters of Crăsnița] (Merlan \& Hapaleț, 2006, p. 52), while the names Dealul Crăsniţa [The Crăsnița Hill] or the version with the denominator in genitive Dealul Crăsniței [The Hill of Crăsnița], Pădurea Crăsnița [The Crăsnița Forest] (ATLAS MOLD.), Iazul Crăsnița [The Crăsnița Pond] (Merlan \& Hapaleț, 2006, p. 18) and Podişul Crăsniței [The Plateau of Crăsnița] (ibidem, p. 16) were formed through polarization. Since in this area we found that an estate with the name Crasna Seacă [Dry Crasna] was attested in the first half of the $19^{\text {th }}$ century near the village of Dolhești (see TTRM, $I_{1}$, p. 308), we do not exclude the possibility that this stream of water was also called Crasna Seacă.

In some sources (HARTA MIL., for instance) Crăsniţa designates the upper stream of Crasna. Hence there appeared through differentiation the name for the springs area: Fundul Crăsniței [The Bottom of Crăsnița]. The two names-Crasna and Crăsnița-were even used simultaneously for identifying the upper stream of Crasna, as indicated by various documents or maps. For instance, in the period 18251858, the estate situated in that area was called either Crasna, Fundul Crasnei, Fundul Crăsniței or Crăsnița (TTRM, $\mathrm{I}_{2}$, p. 1005); a hermitage situated here is mentioned with the names Fundul Crasnei (TTRM, $\mathrm{I}_{2}$, p. 1005), Schitul de la Crăsnița [The Hermitage from Crăsnița], Schitul Crăsnița [Crăsnița Hermitage] or Schitul din Crasna [Crasna Hermitage] (see Costăchescu, 1924, p. 317, 319, 320) ${ }^{4}$. On the estate mentioned above the village known today as Rotăria was settled, which was called, over the years Rotarul [The Wheelwright] or Rotarul din Fundul Crasnei [The Wheelwright in Crasna Bottom], Rotarii [The Wheelwrights], Cräsnița, Crasna and Fundul Crasnei (TTRM, I 2 , p. 1005).

A document from 1535 mentions the Zavalnești village, on Crăsnișoara, a village close to Gugești in the county of Vaslui (DIR, A, XVI-I, p. 378), while a document from 1594 mentions the village of Liești, situated "between Crasna and Crăsnișoara" (DRH, A, IX, p. 178); this village no longer exists today, but its name was preserved in the toponym Valea Liești [Liești Valley] (ROM., 40). The information provided by these two documents entitle us to conclude that the hydronym Crăsnişoara (formed through derivation with the diminutive suffix -işoara) indicates another right-side tributary of Crasna stream, most probably the one known today as Pîrîul Bălțați [Bălțați Stream], after the name of the village in its vicinity ${ }^{5}$. The area near the springs was named through a process of toponymic differentiation: Obîrşia Crăsnişoarei [The Headwaters of Crăsnișoara] (DIR, A, XVI-I, p. 221). The same tributary is mentioned, three years later, as

\footnotetext{
${ }^{4} \mathrm{~A}$ hydronym was formed through polarization from the name of this religious settlement: Pîrîul Schitului [The Hermitage Stream], the name of a right-side tributary of Crasna upstream of the village of Pietris, in the county of Vaslui (Costăchescu, 1924, p. 318).

${ }^{5}$ We do not exclude the hypothesis that this tributary is the Burghina Stream, located South of Bălțați Stream.
} 
Crăsniţa (DRH, A, IX, p. 315).

The diminutive derivates attested over the years designate both the upper part of the stream and several of its tributaries, reflecting a popular denominative modality, common also for other watercourses (Bistrița, Bîrlad, etc.). The intervention of administrative representatives and geographers in the denomination process resulted in the enforcement of other names for some tributaries, usually derived from the names of the villages crossed by the respective watercourses.

We have also identified several hills in the vicinity of this watercourse whose names belong to the toponymic field under analysis: a hill in the upper basin of Crasna stream, near the village of Rotăria (ROM., 40), one West of the village of (MDG, I, p. 119), one West of the town of Huși (CDM, V, p. 203 ${ }^{6}$ ) and another one between Crasna and Lohan (ATLAS MOLD.). The binomial appellation Crasna/Crăsnița is likely to have led to certain errors regarding some geographical objects represented on the maps. Most sources indicate the presence of Dealului Crăsnița [The Crăsnița Hill] on the right side of the Crasna River, near the Crăsnița Creek, from which the name was most probably taken, while the Crasna Hill is located on the left side of the watercourse. However, on the HARTA MIL. of 1962, the two hills are represented in reversed positions; as well as this, in MDG (III, p. 169) the hill near the Crăsnița mound is named The Crasna Hill. From the landform name Dealul Crasna [The Crasna Hill] designating a hill situated in the vicinity of Crasna springs, the following names were formed through differentiation Culmea Dealului Crasna [The Crasna Hill Peak], Muchia Crasna [The Crasna Hill Peak] (Atlas Mold.) and Pădurea Dealului Crasna [The Crasna Hill Forest] (Merlan \& Hapaleț, 2006, p. 113).

As shown above, the names of some villages and estates resulted from the name of the Crasna stream; besides the village situated at the confluence with the Bîrlad River and the village in the vicinity of the springs, called today Rotăria, we have identified two estates whose names are included in the denominative complex formed around the hydronym Crasna. In DRH, A, XX there are a few documents from the first half of the $17^{\text {th }}$ century that mention a certain Crasna which the editors identify as Crasna village from the area where the Crasna Stream flows into the Bîrlad River (DRH, A, XX, p. 769). However, after a careful analysis of these documents (DRH, A, XX, p. 193, 212-213 and 358) and after tracing the boundaries of the village of Broșteni, to which the decisions contained in those documents make reference, we feel entitled to conclude that this is actually another estate called Crasna, situated West of the town of Huși ${ }^{7}$. This hypothesis is supported and confirmed by a piece of information provided by Caproșu (2000, p. 359): two Greek gardeners, a Russian furrier and two former serfs "live in Crasna, in the village of Tătărani"; TTRM, $\mathrm{I}_{1}$, p. 312 attests the existence in this area of an estate called Crasna (which in 1907 was included in the estate of the village of Crețești in Vaslui county). As well as this, another estate should have existed in the middle basin of Crasna, in Rippele Crasnei [The Crasna Steeps], where some fugitives from the village of Băhnarii settled in 1742 (Mihordea, 1961, p. 265).

As proven by the documents, there were many ponds on Crasna, one of them attested in 1493 by the periphrasis Iezerul de la Crasna [The Crasna Lake] (in original w3єра ма краснои, DRH, A, III, p. 254, year 1493), in the vicinity of the present-day village of Tălpigeni in Vaslui. Another toponym of the field that makes the object of this study is Pădurea Crasnei [The Crasna Forest] (MDG, II, p. 41) or Codrul Crasnei [The Crasna Woods] (Giurescu, 1967, p. 40) ${ }^{8}$. Of the secondary toponyms formed from the hydronym Crasna we should also mention: Șesul Crasnei [The Crasna Plain] (TEZ.vas., p. 132; MDG, II, p. 750 and V, p. 553), Podul peste Crasna [The Bridge over Crasna] (Chirica \& Tanasachi, 1984, p. 129), Piscul

\footnotetext{
${ }^{6} \mathrm{~A}$ proof that these oronyms were formed through polarization from the hydronym is the attestation of the toponymic collocation Dealul Văii Crasnei [The Hill of Crasna Valley] (to designate the hill at the boundary with the town of Huși) in a document dating from 1705 (CDM, V, p. 107). Subsequently, through simplification, the name became Dealul Crasnei.

${ }^{7}$ One of the witnesses to the sale of a part of the Crasna estate, in the county of Fălciu, near the boundary of Stroiești, hence West of Huși, was, in 1691, Postolache Coșescul from Crasna (TEZ. vAS., p. 55).

${ }^{8}$ The forest is mentioned in the Annals written by the Polish chronicler Jan Długosz, „in silva post villam Krassne”, besides the stream and the plain it crossed: „in campo, qui Krasnepolye appellatur, ad torrentem Krasni potok” (apud Antoche, 2013, p. 16 and 19).
} 
Crasnei [The Crasna Peak] and Drumul Crasnei [The Crasna Road] (CDM, V, p. 239), Lunca Pîrîlui Crasna [The Crasna Stream Meadow] (Merlan \& Hapaleț, 2006, p. 11), Microdepresiunea Crasna [The Crasna Microdepression] and Podişul Crasnei [The Crasna Plateau] (the last two are geographical terms).

This toponymic field also includes Ocolul Crasna, a name designating two administrative units belonging to Vaslui and Fălciu, respectively, each including several settlements situated in the Crasna drainage basin (TTRM, $I_{2}$, p. 1432-1434).

\section{Morphological and syntactic aspects}

The nucleus-toponym occurs in most cases in its simple form, accompanied by a term that indicates a geographical class (apă 'water', pîrîu 'stream', vale 'valley'), which is embodied in its content. However, along time, it also occurs in collocations containing a determinant either in the genitive (Apa Crasnei [The Water of Crasna] DIR, A, XVI-II, p. 114; Pîrîl Crasnei [The Stream of Crasna] DRH, A, VI, p. 170; Valea Crasnei [The Valley of Crasna] MDG, II, p. 747) or in the nominative (Apa Crasna [The Crasna Water] CDM, IV, p. 439; Pîriul Crasna [The Crasna Stream] DRH, A, XXII, p. 72; Valea Crasna [The Crasna Valley] MDG, IV, p. 37, there are also cases where the quality of the watercourse is overrated, as in Riul Crasna [The Crasna River], Merlan \& Hapaleț, 2006, p. 10). In the foreign maps, the name of this watercourse occurs frequently as semi-calque: Krasna Fl[euve] (year 1781), Krasna Riv[ière] (year 1696), Knisna Fl[uss] (year 1788), Krasna Fl[uss] (year 1787), Krasna F[iume] (year 1788), Krasna Fl[uvius] (year 1774), Crasna $R[e k a]$ (in 1772), $R\left[\right.$ eka] Cracni (year 1774) (see TTRM, $\mathrm{I}_{4}$, p. 63).

The field of the toponym Crasna comprises simple topic names, either derived of complex ${ }^{9}$. The simple ones are names of human settlements Crasna, resulting from a simplification process from a periphrastic construction ( ${ }^{*}$ Satul de pe Crasna [*The Village on Crasna]) or collocation ( ${ }^{*}$ Satul Crasna [*The Village of Crasna]). The toponyms obtained through derivation are Crăsniţa and Crăsnişoara [The Little Crasna]; the derivation with diminutive prefixes is specific to the process of toponymic differentiation and expresses the opposition "main watercourse" - "tributary" or "main watercourse" - "upper watercourse".

Most names resulted from polarization are usually collocations "with a unique determiner, namely the primary toponym or multiple determinata representing terms that designate the class of geographical objects" (Moldovanu, 2010, p. 18). The toponyms derived from the hydronym Crasna make no exception: Dealul Crăsnița [The Crăsniţa Hill], Pădurea Crasnei [The Crasna Forest], Rîpele Crasnii [The Crasna Steeps], Sesul Crasnei [The Crasna Plain], etc. Periphrastic constructions are also present in the field: Iezerul de la Crasna [The Mountain Lake from Crasna], Podul peste Crasna [The Bridge over Crasna], Schitul de la Crăsnița [The Hermitage from Crasna]. Moreover, toponymic differentiation may create collocations. Thus, parts of the denominated geographical object are designated with the help of certain lexical marks (Moldovanu, 2010, p. 19): Dealul Crasna [The Crasna Hill] - Culmea Dealului Crasna [The Crasna Hill Peak], Crasna - Gura Crasnei [The Mouth of Crasna], Crăsnița - Fundul Crăsniței [The Bottom of Crăsnița].

Except for some names that are specific to the geographical scientific register, the elements that form the toponymic structure developed around the hydronym Crasna result from formation procedures that are typical to the Romanian folk toponymy.

\footnotetext{
${ }^{9}$ By complex toponyms we mean names of places made of several terms: periphrasis and toponymic collocations or compound toponyms. By using this term we take distance from most studies on toponymy that regard all toponyms made of several words as compound toponyms. In our opinion, compound toponyms are only those toponyms which, as in the case of common nouns, display "certain inflexion particularities deriving from the total or partial loss of the autonomy of all or some of their constitutive terms" (GLR, I, I, p. 92). For a detailed account on this topic, see Moldovanu (1991, p. LIX).
} 


\section{Conclusions}

The toponymic field formed around the nucleus-toponym Crasna is a very rich and diverse one, as far as the types of names resulted from structural processes of polarization and differentiations are concerned (these processes were transposed in theory by Dragoș Moldovanu). By studying names of places and gathering information from document collections, dictionaries, maps and monographs we have managed to point at the complexity of this denominative ensemble, the evolution of toponyms and the relationships between them, the presence of homonyms and the denominative concurrence. The morphological and syntactical analysis indicated that, except for some geographical names, all toponyms belonging to the field result from formation procedures that are typical to the Romanian folk toponymy. The Annex provides a schematic account of this denominative ensemble made of toponymic derivates of various degrees developed from the polarizing toponym Crasna.

\section{Bibliography}

\section{A. References}

Antoche, E.C. (2013). L'expédition polonaise de 1450 en Moldavie et la bataille de la petite rivière de Crasna (Izvorul Crasnei, 6 septembrie 1450), in "Rocznik Przemyski", 49, p. 3-24.

Bolocan, Gh. (1977). Transferul de nume în toponimie, in "Studii și cercetări lingvistice", XXVIII, nr. 2, p. 171-180.

Caproșu, I. (2000). Documente privitoare la istoria orașului Iași, Editura Dosoftei, Iaşi.

Chirica, V. \& Tanasachi, M. (1984). Repertoriul arbeologic al județului Iași, vol. I, Iași.

Chiriță, C. (1893). Dicționar geografic al județului Fălciu, Tipografia Petru C. Popovici, Iași.

Ciubotaru, M. (1992). [recenzie la] Alexandru I. Gonța, Documente privind istoria României. A. Moldova. Veacurile XIV-XVII (1384-1625). Indicele numelor de locuri, Editura Academiei Române, București, 1990, in "Anuarul Institutului de Istorie «A.D. Xenopol»", XXIX, 1992, p. 457-459.

Ciubotaru, M. (2001). Oronimia și bidronimia din bazinul superior al Bîrladului, Casa Editorială Demiurg, Iași.

Costăchescu, M. (1924). Schitul de la Crăsnița (Vaslui), in "Ion Neculce", IV, p. 317-320.

Drăganu, N. (1933). Românii in veacurile IX-XIV pe baza toponimiei și a onomasticei, Imprimeria Națională, București.

Ghibănescu, Gh. (1913). Surete și izvoade. Vol. VIII, Tipografia „Dacia” P\&D. Iliescu, Iaşi.

Ghibănescu, Gh. (1926). Sureteși izvoade. Vol. XV. Vasluiul. Studiu şi documente, Institutul de arte grafice „Viața românească”, Iaşi.

Giurescu, C. C. (1967). Istoria pădurii românești din cele mai vechi timpuri pinnă astăzi, Editura Ceres, București.

Gonța, Al. (1977). Rolul cancelariei moldovenești in slavizarea numelor de locuri in secolele XIV-XVI (Originea istorică a Cobîlelor), in "Anuarul Institutului de Istorie și Arheologie «A.D. Xenopol»", XIV, p. 261-275.

Gonța, Al. (1995). Documente privind istoria României. A. Moldova. Veacurile XIV-XVII (1384-1625). Indicele numelor de persoane, Editura Academiei Române, București.

Grinčenko, B.D. (1925). Slovar’ ukrainskogo jazyka, Derjavne Vidavnițvo Ukraini, Kiev.

Gugiuman, I., Cîrcotă, V. \& Baican, V. (1988). Diç̦ionar geografic al județului Vaslui, Centrul de multiplicare al Universității „Alexandru Ioan Cuza", Iași.

Iordan, I. (1963). Toponimia românească, Editura Academiei, București.

Lupu, I. \& Kalinca, R. (1990). Linia ferată Crasna-Huși. O sută de ani. (15 X 1890-15 X 1990). Completări monografice, Regionala Căii Ferate, Iași.

Merlan, V. \& Hapaleț, G. (2006). Monografia comunei Dolhești, județul Iaşi. 666 de ani de atestare documentară, Iași, Editura Lumen.

Mihordea, V. (1961). Documente privind relațiile agrare in veacul al XVIII-lea, vol. II, Editura Academiei, București.

Miklosich, Fr. (1862-1865). Lexicon paleoslovenico-greco-latinum emendatum auctum, Guilelmus Braumueller, Viena.

Miklosich, Fr. (1927). Die Bildung der slavischen Personen- und Ortsnamen, Carl Winters Universitätsbuchhandlung, Heidelberg.

Moldovanu, D. (1972). Principii ale lexicografiei toponimice, in “Anuar de lingvistică și istorie literară”, XXIII, p. 73-100.

Moldovanu, D. (1991). Introduction to TTRM, $\mathrm{I}_{1}$.

Moldovanu, D. (2010). Teoria cimpurilor toponimice (cu aplicație la cîmpul hidronimului Moldova), Editura Universității „Alexandru Ioan Cuza”, Iași.

Petrovici, E. (1970). Studii de dialectologie și toponimie, Editura Academiei, București.

Rezeanu, A. (2014). Periplu toponimic, Editura Academiei Române, București.

Šmilauer, V. (1970). Handbuch der slawischen Toponomastik, Československé akademia věd, Praga. 
Ujvári, I. (1972). Geografia apelor României, București, Editura Științifică.

Vasmer, M. (1967). Etimologičeskij slovar' russkogo jazyka (translation and notes by O.N. Trubačev), II, Izdatelstvo Progress, Moskva.

\section{B. Acronyms}

ATLAS MOLD. = Institutul Geografic al Armatei, Atlasul Moldovei (1:50 000), București, 1892-1898.

CDM = Catalogul documentelor moldovenești din Arbiva Istorică Centrală a Statului, I (1387-1620), II (1621-1652), III

(1653-1675), IV (1676-1700), V (1701-1720), București, 1957, 1959, 1968, 1970, 1975.

DIR, A = Documente privind istoria României. A. Moldova, Editura Academiei, București, 1951-1957.

DRH, A = Documenta Romanic Historica. A. Moldova, I-XXVII, București, 1975-2006.

GLR, I = Gramatica limbii române. I. Cuvîntul, Valeria Guțu Romalo (coord.), București, Editura Academiei Române, 2005.

HARTA MIL. = Harta R.S. România, executată de Direcția Topografică Militară, (1:25 000), București, 1962.

MDG = George Ioan Lahovari (coord.), Marele dicționar geografic al României, I-V, Socec, București, 1898-1902.

MDTM = Mic dicționar toponimic al Moldovei, structural și toponimic. Partea I. Toponime personale, Dragoș Moldovanu (coord.), Editura Universității „Alexandru Ioan Cuza”, Iași, 2014.

RoM. = România. Atlas rutier, de general maior ing. Vasile Dragomir, col. ing. Victor Balea, col. ing. Gheorghe Mureșanu,

Gheorghe Epuran (sc. 1:350 000), Editura Flomarco, București, 1981.

TEZ.vas. = Din tezaurul arbivistic vasluian. Catalog de documente, 1399-1877, întocmit de Grigore Găneț şi Costică-Ioan Gârneață, București, 1986.

TTRM, $\mathrm{I}_{1-2}=$ Tezaurul toponimic al României. Moldova. $\mathrm{I}_{1-2}$, Repertoriul istoric al unităţilor administrativ-teritoriale (17721988), Dragoș Moldovanu (coord.), București, 1991-1992.

TTRм, $\mathrm{I}_{4}=$ Tezaurul toponimic al României. Moldova. $\mathrm{I}_{4}$, Toponimia Moldovei în cartografia europeană veche (cca 1395-1789),

Dragoș Moldovanu (autor), Iași, 2005. 


\section{Appendix A. Crasna toponymic field}

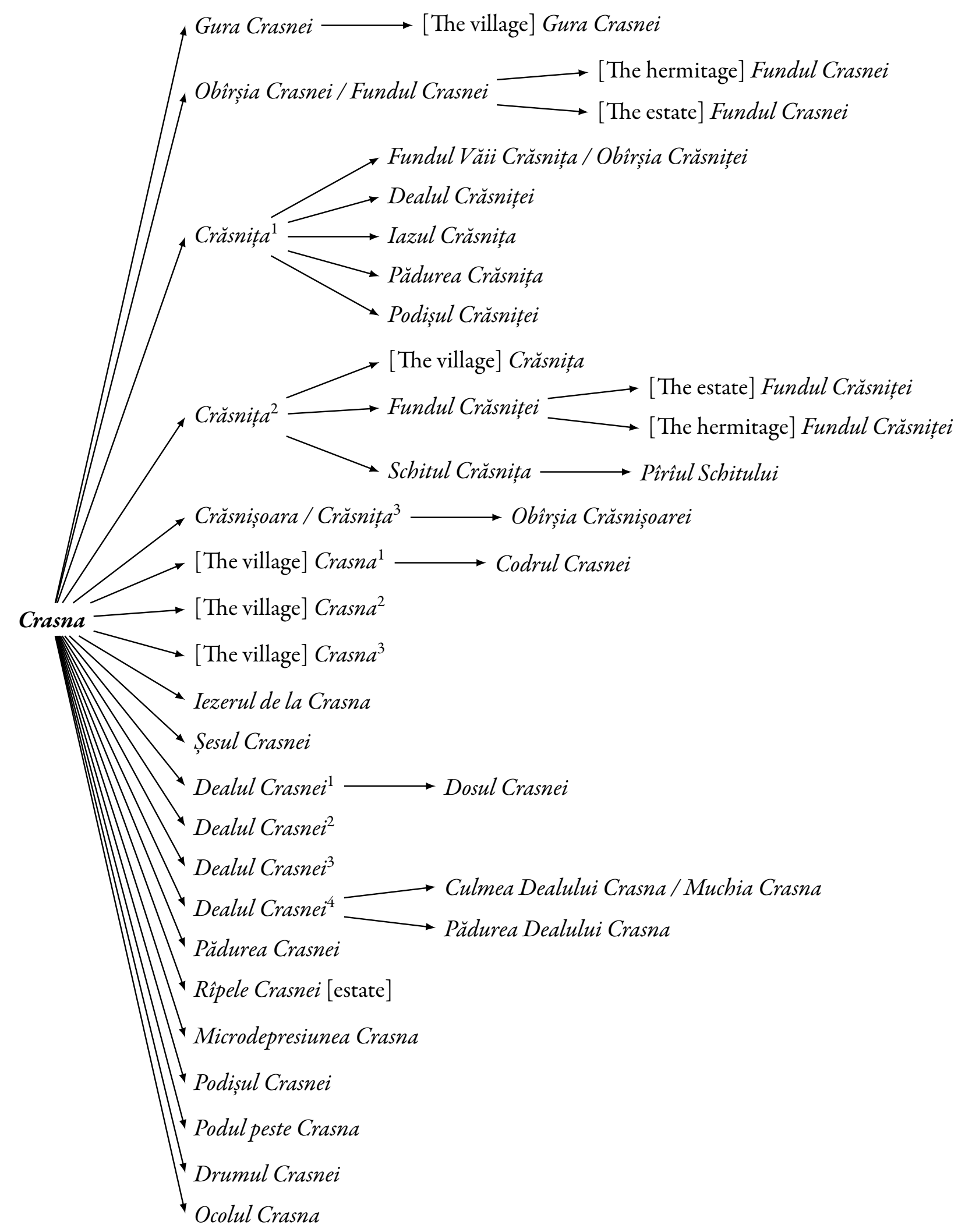

